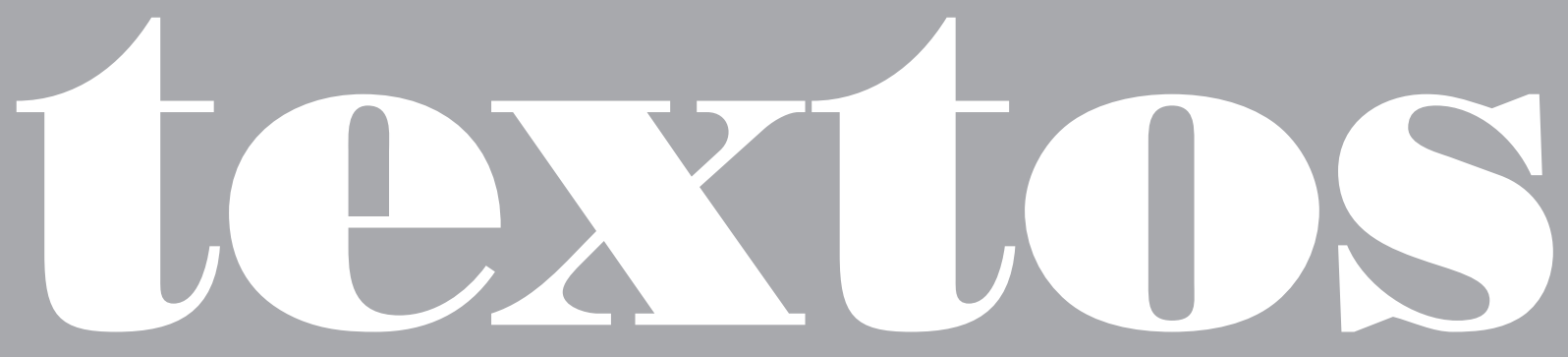





\title{
O Conde de Monte Cristo e a catábase de Edmond Dantès
}

\author{
Cleber Vinicius do Amaral Felipe
}

"Há no crime limite se um crime praticas, não se o devolves"

(Sêneca)

"Anjo só de bondade, sabeis do furor, Lágrimas de fel, punho na sombra crispado, Na hora em que a Vingança, em infernal chamado, De nossas faculdades torna-se o mentor? Anjo só de bondade, sabeis do furor?"

(Charles Baudelaire)

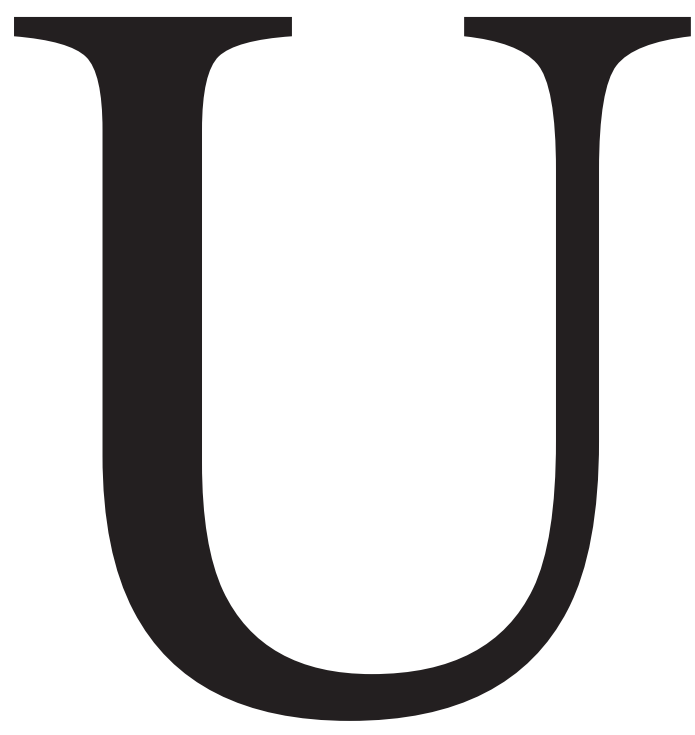

"Ai! Que vale a vingança, pobre amigo. Se na vingança, a honra não se lava?"

(Castro Alves)

ma denúncia anônima arruinou a vida de Edmond Dantès, protagonista do romance $O$ Conde de Monte Cristo (1844-1846). Acusado de alta traição e envolvimento com bonapartistas, ele passou 14 anos encarcerado nas masmorras do castelo de If. Na prisão, Dantès experienciou uma "iniciação" sem a qual não teria encontrado condições para 
arquitetar e colocar em prática sua vingança. Não por acaso, em um dos ensaios do livro Tese e antítese (1964), Antonio Candido interpretou o romance como um "tratado da vingança". O episódio envolvendo o cárcere do protagonista apresenta características compatíveis com as de uma catábase, termo que designa um antigo ritual em que personagens excepcionais como Hércules e Odisseu visitavam, ainda vivos, o mundo dos mortos. Embora Alexandre Dumas não retrate encontros com espectros errantes ou rotas de acesso ao submundo, pretende-se demonstrar a analogia por tratar-se de uma chave de leitura verossímil. Ao mesmo tempo, analisam-se alguns recursos empregados pelo romancista na construção de um locus horrendus insular, sediado em um forte construído no século XVI e convertido em prisão na centúria seguinte.

\section{A TÓPICA DA VINGANÇA}

A fábula da Ilíada desenrola-se no último ano de um conflito bélico que durou uma década, perfazendo não mais que dois meses. Sua matéria tem início com a contenda entre Aquiles e Agamêmnon e termina com o resgate do príncipe Heitor, quando uma trégua entre aqueus e troianos foi acordada para que os rituais fúnebres fossem cumpridos. O herói, no universo homérico, pode ser forte, bravo e corajoso. Se ele porventura negligenciar a "piedade", decerto, será vítima de castigo divino.

De acordo com André Malta (2001, p. 79), a piedade pode ser concebida com um sentido religioso, de "devoção aos valores que regem a relação entre os homens e Deus, e também a relação entre os próprios homens", mas pode ser ainda empregada para designar uma atitude pautada na compaixão, categoria que se aproxima à concepção de misericordia latina. A noção de "pena", em Homero, aparece, com frequência, associada a uma situação de súplica: o homem que suplica coloca-se na condição de dependente, de inferior. É, pois, a mesma posição assumida pelo sacerdote Crises quando, no primeiro canto da Ilíada, solicitou a Agamêmnon a devolução de sua filha, Criseida. A recusa por parte do Atrida demonstrou falta de misericórdia e, consequentemente, vários aqueus foram aniquilados pelas flechas de Apolo. O rei acabou aquiescendo e devolveu a filha ao sacerdote, só que, em contrapartida, tomou para si uma escrava de Aquiles, despertando sua ira (mênis) e o levando a ausentar-se da guerra. O herói sentiu-se humilhado quando a dignidade real sobrepujou a honra guerreira. Como o combatente arriscava-se no campo de batalha e corria o risco de ter sua vida abreviada, era de se esperar que seu espólio fosse assegurado.

No canto IX, numa tentativa de redimir-se, o rei enviou uma embaixada para requisitar o retorno do Pelida. Fênix, um dos membros da comitiva, perante a recusa de Aquiles (que, por não atender às súplicas de Agamêmnon, foi vítima da áte, da perdição), afirmou ser ele portador de "entranha impiedosa". Tomando como base a noção de perdição, André Malta sugeriu a presença de dois ciclos na Ilíada: o de Agamêmnon, do início do poema ao canto IX, e o de Aquiles, do canto IX em diante, quando o herói, depois de um prolongado luto pelo companheiro Pátroclo, aplacou sua fúria, apiedou-se do rei troiano e devolveu 
o corpo de Heitor. A tentativa de ultrajar o cadáver do príncipe troiano, arrastando-o, dia a dia, ao redor de sua tenda, é um indicador de hýbris, isto é, de falta de comedimento. Sua intenção foi causar ao seu desafeto várias mortes, desfigurar seu corpo e impedir os rituais fúnebres, condição para uma bela morte (kalòs thánatos), única forma de se conquistar fama imorredoura (kléos) $)^{1}$. Ao apiedar-se de Príamo, Aquiles interrompeu sua sede vingativa, porém sem a vingança os aqueus voltariam para suas casas derrotados.

A matéria da tragédia Tiestes, de Sêneca, retoma um tema frequente na dramaturgia greco-romana: o mito dos Pelópidas envolvendo o conflito entre Atreu, pai de Agamêmnon, e Tiestes. Sob pretexto de estabelecer a paz, o primeiro, dominado pela fúria vingativa ${ }^{2}$, arquitetou um plano horrendo para abalar até mesmo os fundamentos do cosmos, a ponto de os deuses partirem para longe com o intuito de não presenciarem o banquete sangrento e inglório. Incapaz de perdoar o irmão, o rei enviou-lhe uma proposta de paz e ofereceu-lhe participação no trono, sugerindo uma monarquia dual. A princípio temeroso, Tiestes, estoicamente, retrocedeu, mas ao fim se deixou convencer. Para selar a "aliança fraterna", que dissimulava a hýbris, Atreu sacrificou os filhos do seu irmão e os serviu como repasto num banquete. O crime, de tão severo, estimulou prodígios, como o cessar e o

1 Sobre a bela morte, ver: Vernant (1978).

2 Tiestes havia urdido, com a esposa de Atreu e sua amante, um plano para conquistar o trono de Micenas. Entretanto, como a ação criminosa foi desvendada, Atreu assumiu o trono e Tiestes partiu para o exílio. retroceder do Sol. Um dos motivos é que, para colocá-lo em prática, seu mentor precisou simular os dons do acolhimento.

A atitude de Atreu pode ser compreendida como scelus nefas, crime sacrílego que ocasiona o desequilíbrio cósmico. Sua fúria acaba fazendo-o tomar por virtudes práticas viciosas:

\section{“[...] E o que é a afronta}

máxima, creio, a um soberano onipotente: não vingar-se!"

(Sêneca, 2018, p. 27).

A sede de vingança era tamanha que só um crime sem precedentes poderia suplantá-la:

\section{"[...] O pai, voraz, lacere}

os filhos, deliciado, e devore seus membros. Bravo! É o bastante! Apraz-me esse grau [de vingança por ora"

(Sêneca, 2018, p. 39).

Antes do banquete nefasto, Tiestes buscou se redimir com o irmão recorrendo à súplica, temática identificada também na Ilíada:

\section{“[...] É, decerto, culpado}

quem a tão bom irmão pareceu ser culpado. Apelo às lágrimas. Só tu me viste em súplica, imploram-te estas mãos que outros pés não

[tocaram; deixemos toda ira e na alma seja extinto o orgulho"

(Sêneca, 2018, p. 61).

No entanto, como disse o mensageiro ao ser questionado pelo coro, uma vingança convencional, como a privação das honras fúnebres, não seria cruel o suficiente: 


\section{"CORO}

E pôde mais? Deu-os às feras

p'ra lacerar seus corpos, privando-os da pira? MENSAGEIRO

Assim fosse! Deixasse sobre o chão os mortos, nem fogo os consumisse, às aves e a vorazes feras fizesse-os arrojar, triste repasto" (Sêneca, 2018, pp. 81-3).

Arquiteto de um banquete que subvertesse todos os pilares da boa e velha hospitalidade, Atreu não pôde deixar de se regozijar, desafiando os deuses:

"Ando de par com os astros e os supero

[todos!

Atinge o alto dos céus a minha fronte altiva! Obtenho agora o emblema e o trono de meu

[pai.

Dispenso os deuses; alcancei meus votos

[todos.

Bravo! É o bastante! Eu mesmo estou já

[satisfeito.

Mas deveria? Avante, irei fartar o pai

da mortualha dos seus. P'ra tolher-me o

[pudor,

recuou o dia. Avante, enquanto vaga o céu.

Quem me dera deter os deuses fugitivos

e trazê-los à força, todos, p'ra que vissem

a ceia da vingança. Vê-la o pai já basta"

(Sêneca, 2018, pp. 91-3).

É possível efetuar a leitura das tragédias de Sêneca a partir de dois movimentos, responsáveis pela ação nefasta: a passagem do dolor (que impulsiona a ação trágica na medida em que estimula a revanche contra uma injúria cometida) para o furor (movido pela cólera, pela insânia, pela falta da prudentia estoica) e, em seguida, a concretização do nefas, do crime propriamente dito. Desta feita, o homem transforma-se em "monstro" e, ao mesmo tempo, abala a ordem cósmica. Atreu maquinou o desagravo, moveu sua cólera contra o irmão, valeu-se da razão para armar uma emboscada e, depois de cometida a hýbris, agiu com soberba frente aos deuses e congratulou-se pela maneira como o crime foi desempenhado com excelência. Quando informado sobre a ação vingativa, Tiestes, tomado pelo furor, conjurou contra o irmão a vingança dos deuses. O ciclo continuaria a se repetir até que uma das partes conseguisse suspendê-lo ${ }^{3}$.

Nos dois exemplos referidos (homérico e senequiano), a intensidade da represália supera a da ação que a desencadeou. Além disso, é possível notar certo descompasso entre a fúria vingativa e a vontade dos deuses, de modo especial na tragédia senequiana. Como veremos, no caso do romance de Dumas, a retaliação é retratada de outra maneira, talvez porque o século XIX tenha cunhado uma nova noção de indivíduo.

\section{O ROMANCE DE DUMAS}

A vingança, de acordo com Antonio Candido, é uma chave de leitura do romance Le Comte de Monte Cristo, publicado no Journal des Débats, entre agosto de 1844 e janeiro de 1846. No rodapé do jornal, que os franceses chamavam de feuilleton (folhetim), os leitores se deleitavam com piadas, enigmas, receitas, boletins de moda e outros gêneros de entretenimento. Em 1836, passou a abrigar também romances,

3 Sobre o assunto, ver: Dibbern (2010, pp. 4-13). 
quando Émile de Girardin, proprietário do La Presse, encomendou de Balzac a obra intitulada La vieille fille.

Dumas contribuiu com o estabelecimento do gênero ao publicar Le capitaine Paul em 1838 no periódico Le Siècle. Esse modelo de ficção seriada incentivou uma forma diferente de produzir literatura e, com isso, diversificou também o público leitor ${ }^{4}$, acarretando uma série de críticas por parte de escritores da época. Em 1839, por exemplo, Sainte-Beuve escreveu um artigo intitulado "De la littérature industrielle", onde afirmou que o romance folhetim prejudicava o papel desempenhado pela crítica literária, que não alcançava o público com a mesma eficácia que o jornal. Além disso, como os escritores recebiam por linha, os romances acabaram sendo inflados com diálogos e descrições, o que prejudicou sua excelência (Ribeiro, 1996, pp. 27-8). Eugène de Mirecourt, alguns anos depois, publicou um panfleto acusando Dumas de ser um "escritor industrial" que empregava outros literatos sem atribuir-lhes coautoria (Torres, 2012, pp. 1-26).

A trama, repleta de minúcias e de peripécias acessórias, possui um fio condutor: a trajetória de Edmond Dantès, imediato do navio de três mastros Pharaon. Desprovido de ganância, esse marinheiro almejava tornar-se capitão tão somente para cuidar melhor de seu velho pai e oferecer um casamento digno a Mercedes, uma jovem catalã que lhe devotava um amor sincero. Entretanto, a ambição da qual era desprovido abundava no coração de seus desafetos: Danglars, contador do Pharaon, desejava

4 Sobre o romance folhetim, ver: Meyer (1996); Nadaf (2009). seu cargo; Fernand cobiçava o amor de Mercedes; o juiz Villefort, por fim, ambicionava o cargo de procurador do rei. $\mathrm{O}$ mesmo trio foi responsável pela acusação de traição e pela prisão do protagonista, que passou 14 anos no horrendo castelo situado na Ilha de If.

Durante a prisão, Dantès conheceu o abade Faria, preso político e detentor de grande sabedoria. $\mathrm{O}$ diretor da prisão e os carcereiros consideravam-no louco, pois o velho padre dizia conhecer o paradeiro de uma fortuna sem precedentes, outrora pertencente ao cardeal Spada. Os dois prisioneiros tentaram cavar uma rota de fuga por anos e, no decorrer desse penoso trabalho, o abade ensinou a Dantès tudo o que sabia. Entretanto, seus planos foram frustrados e o velho mentor foi vitimado por uma doença mortal. Seu corpo foi revestido por uma mortalha e deixado na cela para ser transportado à noite. Dantès, que frequentava a cela do abade por um túnel, ocultou o corpo do defunto e vestiu a mortalha, aguardando uma ocasião para fugir. O pobre protagonista ignorava que o cemitério de If fosse o mar bravio: depois de arremessado, conseguiu nadar até uma ilha próxima. Mais tarde, encontrou o tesouro enterrado na Ilha de Monte Cristo graças às informações de seu finado mestre, deixando de lado sua antiga identidade, para tornar-se um misterioso conde.

Em liberdade, ele colocou em prática o plano de vingança que arquitetou durante sua estadia na prisão, portando-se como instrumento da Providência a distribuir justiça contra seus inimigos. Não obstante a eficácia de seus planos, ao final da jornada e depois de receber lições implacáveis, ele próprio foi desenganado quanto aos efeitos da sede 
vingativa, perdoando Danglars, após criar condições que ocasionaram o suicídio de Fernand e o enlouquecimento de Villefort.

\section{CÁRCERE DE DANTÈS SEGUNDO ANTONIO CANDIDO}

De acordo com Antonio Candido (2017, pp. 1-28), quando, enfim, colocou os pés na Ilha de Monte Cristo e atingiu seu cume, o protagonista estava a um passo de confirmar o que, antes, considerava impossível: as incomensuráveis riquezas do cardeal Spada eram reais e aguardavam por ele, no subsolo da ilha. Como observou Candido, Dantès se encontrava entre dois polos da imaginação humana - a montanha, de onde ele descortinou o mundo, e a caverna, onde os mistérios que confeririam a ele poder estavam ocultos. De um lado, "o pináculo que amplia"; de outro, o "recesso que concentra". Os lugares prediletos dos românticos, segundo o autor, envolviam torres, morros, picos de ilhas, que tornavam possível o encontro do homem com seu sonho de liberdade e/ou poder. Mas nosso interesse deter-se-á no subsolo, nos recônditos cavernosos, nas entranhas escuras, nas grutas ocultas em uma ilha.

Desejoso de distribuir a justiça de Deus, Dantès queria se tornar uma das molas ocultas da Providência, ainda que essa transformação implicasse um pacto com o Diabo. Poderíamos avançar com uma análise psicológica, dizendo que Dantès atua no romance como um pináculo, como uma persona que oculta, no seu íntimo, um outro mundo que se desdobraria à medida que ele colocasse em prática sua retaliação; que ele busca, na Providência, refúgio de modo a relacionar suas ações à vontade divina. Não por acaso, Antonio Candido vai conceber o romance como um tratado de vingança afinado ao individualismo burguês. A ficção seriada, de acordo com este crítico, favoreceria esse lugar-comum, saciando as demandas psicológicas de um público ávido por suspense. A revanche teria permitido ao protagonista uma circulação pela escala social e proporcionado um retrato da complexa alma humana. Sendo assim, de rapaz honesto, excelente profissional, filho zeloso, noivo atencioso e amigo fiel, o protagonista tornou-se sábio, solitário, livre, rico e infeliz. Ao final, também experimenta o remorso.

Segundo Candido, Dantès perdeu sua inocência no "purgatório do castelo" de If. Com a ciência, ele também adquiriu consciência do bem e do mal. Antonio Candido menciona um "vingador científico" que, para as personagens, seria o paradigma do homem que domina todos os recursos de seu tempo e, para nós, um grande herói romântico. Belo, elegante, ágil, excêntrico, misterioso, melancólico, infalível, rei dos disfarces.

Villefort, Danglars e Fernand remetem, respectivamente, à corrupção nas esferas jurídica, financeira e militar. No entanto, se de fato o tempo na prisão se assemelha a um processo expiatório (que pressupõe castigos temporários), logo de início já descobrimos a inocência do prisioneiro. Assim, mais pertinente é conceber a estadia de Dantès nos calabouços de If como um período de provações e, também, como uma ocasião de crescimento intelectual e financeiro. Como o indivíduo que desce ao submundo e regressa depois de uma sucessão de desenganos, Dantès experienciou vários sentimentos, inúmeras dores e passou a conhecer teologia, história, matemática, 
economia, filosofia, química e diferentes idiomas - eis as condições para a criação de um homem implacável contra seus desafetos e perito na arte dos disfarces.

\section{DUMAS LEITOR DE DANTE ALIGHIERI}

No Prefácio, Dumas buscou encerrar uma polêmica envolvendo a autoria do seu romance: em tom de gracejo, afirmou que, na Itália, a opinião geral era a de que Dante Alighieri seria o autor da obra. Em seguida, questionou: "Por que não acham que fui eu que escrevi A divina comédia? Nesse aspecto, tenho, exatamente, os mesmos direitos". Alexandre Dumas fez pilhéria daqueles que o acusaram de não ser o autor dos romances que assinava e, ao mesmo tempo, amplificou seus méritos ao dizer que os italianos acreditaram tratar-se de uma produção dantesca. Não se trata de um modelo, de uma auctoritas a ser imitada, mas de uma possível fonte de inspiração.

O motivo que proporcionou o cárcere de Dantès foi a acusação de traição, pecado gravíssimo segundo a concepção escolástica de Dante Alighieri: os traidores, afinal, são punidos no nono círculo infernal. Além disso, é impossível não associar o nome de ambos. $\mathrm{O}$ abade Faria, ao instruir Dantès apresentando-lhe as diferentes ciências que dominava, atuou como Virgílio, que guiou Dante pelos círculos infernais e pelos terraços do Purgatório. Alexandre Dumas conhecia muito bem a Divina comédia, pois mencionou o canto XXXIII do Inferno, quando Ugolino, condenado na condição de traidor, devorava o crânio de um arcebispo (Dumas, 2012, p. 185); em outro momento, citou o canto $X$ para identificar a família Cavalcanti.
No prefácio, para descrever a visão gerada pela Ilha de Monte Cristo, Dumas recorreu a um fragmento do poema de Dante: "Nunca vi manto de anil mais belo do que aquele lançado sobre seus ombros pelo sol nascente" (Dumas, 2012, p. 15). O trecho encontra-se no primeiro canto da Commedia: "Mas, ao chegar ao pé de uma colina onde começava a selva, que se estendia vale abaixo, olhei para cima e vi os ombros do monte cobertos pelos primeiros raios de sol". A semelhança entre os dois fragmentos permite supor a emulação. Em se tratando da descrição de uma colina, poderíamos indagar por que motivo o castelo de If foi abrigado justo no cume de uma ilha. Como poderíamos interpretar a presença de regiões insulares no romance?

\section{AS ILHAS E SEUS MISTÉRIOS}

Numa passagem do canto IX da Odisseia, Polifemo aprisionou Odisseu e devorou seis de seus companheiros, durante o desjejum. Antropofagia e falta de acolhida são duas práticas censuráveis aos olhos do protagonista, pois os homens jamais deveriam consumir alimentos crus, negligenciar as hecatombes, ignorar os rituais de purificação ou deixar de acolher os estrangeiros, práticas condizentes com o ambiente da pólis. Polifemo, ao contrário, zombava de "Zeus hospitaleiro", conduta que causou sua ruína: depois de deixá-lo ébrio, Odisseu perfurou seu único olho e fugiu às pressas na companhia dos sobreviventes. Em momento algum Homero alegou tratar-se de uma ilha, mas o poeta Eurípedes, no século $\mathrm{V}$ a. C., relendo o episódio, em chave satírica, associou a terra dos ciclopes à ilha 
da Sicília, informação que foi repetida na Eneida, de Virgílio (ver Rodrigues, 2016). Logo, a ilha reúne, no seu âmago, personagens míticas que atuam como antípodas do homem excelente detentor da virtude (areté) e merecedor de fama perene (kléos).

É também numa ilha, situada no inabitado/inabitável Hemisfério Sul, que Dante Alighieri situou o Purgatório, representado como altíssima montanha com formato de cone que se ergue até o primeiro orbe do Céu. Diferentemente do Inferno, que é árido e se assemelha a uma cidadela medieval fortificada com muralhas, torres e pontes levadiças, a montanha de expiação dos pecados veniais é coberta de árvores frutíferas e protegida, a cada terraço, por um anjo.

No canto XXVI do Inferno, deparamo-nos com Odisseu, condenado pela sua conduta fraudulenta ao sugerir a construção do cavalo de madeira. O herói homérico contou a Dante que, depois da Guerra de Troia, podendo retornar a Ítaca, optou por explorar o desconhecido, ultrapassando as Colunas de Hércules e sendo engolido pelo mare tenebrarum, quando esteve prestes a alcançar a isolada ilha do Purgatório. Hércules, como é sabido, havia edificado as colunas nos rochedos de Gibraltar e Ceuta para estabelecer um limite não apenas geográfico, mas também filosófico e moral (ver Marques, 2017). Trata-se de um apelo à prudência, virtude que Sêneca (1985, p. 5) recomendou a Lucílio em sua segunda epístola: "não corras o mundo nem te inquietes com mudanças de lugar. Tal agitação é própria de um ânimo enfermo. A primeira prova de uma mente bem-composta é, a meu ver, poder conter-se e residir em si”. Horácio também censurou a inquietude em uma de suas odes - "Feliz aquele que, longe dos negócios,/ como a antiga raça de mortais,/ faz trabalhar seus bois nos campos paternos,/ livre de toda usura,/ e não o acorda, qual a um soldado, a cruel trombeta,/ nem teme o mar bravio,/ e evita o fórum e os soberbos limiares/ dos poderosos" (apud Fonseca, 1967, p. 80).

Alguns navegantes imprudentes desbravaram mares para além do limite estipulado por Hércules. Por volta do século IV a. C., Píteas teria deixado sua terra natal, atual Marselha, para circum-navegar a costa britânica. Depois de atingir o norte da Escócia, avançou cinco ou seis dias até alcançar a última ilha habitada, que ele chamou de Thüle. Fontes modernas sugerem que a ilha em questão seria a Islândia ou a Noruega. Desde então, a tendência foi torná-la o limite do mundo conhecido, daí a expressão latina Ultima Thule. Àquela altura, esse era o limite que apenas homens temerários ousariam ultrapassar. Quando James Cook decretou, por volta de 1775, o seu próprio nec plus ultra, avançando rumo ao sul, chamou a ilha limítrofe de Thüle. Talvez, no que diz respeito ao imaginário polar, os polos fossem tratados de maneira indistinta, ou quem sabe o capitão não fez outra coisa senão imitar a referência antiga, que, muito provavelmente, conhecia (ver Jones, 2010, pp. 51-69). A referida ilha, assim como as ilhas Cook e Bellingshausen, todas fruto de erupções vulcânicas, são conhecidas como Thüle do Sul, região árida, fria e, por consequência, desabitada.

As terras insulares nem sempre carregaram consigo uma conotação negativa, como é o caso da Utopia (1516), ilha que Thomas Morus situou em algum local do Oceano Atlântico meridional, área, até então, pouco conhecida e explorada. De acordo com Frank Lestringant (2006, p. 156), o mun- 
do desenhado pelas viagens marítimas é um "mundo-arquipélago". A ilha, no caso, surge como "elemento privilegiado de uma geografia maleável, cuja forma e desenho são passíveis de infinitas reconstruções, que obedecem a projetos políticos particulares".

Num momento em que o mundo estava sendo cartografado, Morus projetou, em um território insular fictício, um núcleo social que escapava às práticas censuráveis de seu tempo. Algo parecido acontece n'Os lusíadas (1572), de Camões, de modo particular, nos cantos finais, quando o protagonista e seus subordinados passavam pela "Ilha dos Amores". Depois de ultrapassar o mato "árduo, difícil, duro a humano trato", alegoria da vida sensível, dos erros e desvios da condição humana, os nautas lusitanos se uniram às ninfas aquáticas, episódio que remete ao "casamento" de Portugal com o mar. Trata-se, portanto, de uma forma providencial de legitimar a empresa ultramarina, atribuindo poder teológico e político ao domínio da monarquia católica sobre regiões gentias e pagãs (ver Hansen, 2005).

If é um ambiente insular obscuro marcado pela morte e pelo sofrimento. Como nos recorda Montserrat Parra i Albà (1999, p. 111), a ilha é sempre descrita com cenários noturnos. No entanto, o conhecimento decorre deste sofrimento e surge como um tesouro sem o qual sua vingança não se efetivaria. O cenário obscuro parece remeter à ignorância de Dantès; o conhecimento adquirido, por outro lado, concederia acesso a outra ilha, dessa vez bem-aventurada: a Ilha de Monte Cristo, que guardava, em seu âmago, um grande tesouro. Edmond precisou ultrapassar lugares obscuros e superar duras provações para tornar-se, em definitivo, o enigmático conde.
A descrição das ilhas apresenta um contraste digno de nota. A primeira delas, sombria, foi representada da seguinte maneira:

"Dantès levantou-se, dirigiu com naturalidade os olhos para um ponto para o qual parecia se dirigir a embarcação e, a duzentos metros à sua frente, viu-se erguer o rochedo negro e íngreme sobre o qual se assenta, como uma superfetação de sílex, o soturno castelo de If [...]. Aquela forma estranha, aquela prisão em torno da qual reina tão profundo terror, aquela fortaleza que, há trezentos anos, faz Marselha reviver lúgubres tradições, ao surgir assim, repentinamente, para Dantès, que nem sonhava com ela, teve o efeito que ao condenado à morte inspira a visão do cadafalso" (Dumas, 2012, p. 110).

Em uma investigação filosófica publicada em 21 de abril de 1757, Edmund Burke (1993, p. 48) definiu o sublime como algo "capaz de incitar as ideias de dor e de perigo". Vários elementos, ao longo do tratado, foram associados a esse efeito, como, por exemplo, a obscuridade: quando "temos conhecimento de toda a extensão de um perigo, quando conseguimos que nossos olhos a ele se acostumem, boa parte da apreensão desaparece" (Burke, 1993, p. 66). A noite, para Burke, é um cenário bastante apropriado para provocar terror. As privações também são grandiosas, como o são o vazio, as trevas, a solidão e o silêncio. Dumas, para retratar o castelo de If, recorreu a alguns desses expedientes, o que não acontece em relação à Ilha de Monte Cristo:

"Duas horas depois, ele subiu para a ponte; a embarcação dobrava a Ilha de Elba. Estavam na altura de Marciana e acima da 
ilha achatada e verde da Pianosa. Via-se projetado no azul do céu o cume resplandecente de Monte Cristo [...]. Por volta das cinco da tarde, tiveram a visão completa da ilha. Graças à limpidez atmosférica que caracteriza a luz derramada pelos raios do sol poente, percebiam-se seus menores detalhes [...]. Edmond devorava com os olhos aquele bloco de rochas que passava por todas as cores crepusculares, do cor-de-rosa vivo ao azul-escuro; de tempos em tempos, lufadas de ar quente batiam-lhe no rosto; sua testa arroxeava-se, uma nuvem purpúrea passava diante dos seus olhos" (Dumas, 2012, p. 303).

Fica muito nítida a diferença entre o locus horrendus figurado pela ilha que abriga, no seu cume, o castelo de If, e o locus amoenus representado pela Ilha de Monte Cristo. Há um movimento descendente para as catacumbas da prisão e, em seguida, um movimento ascendente rumo aos rochedos que ocultavam, no subterrâneo, um tesouro perdido. A temática da catábase pode nos ajudar a entender melhor o itinerário de Edmond Dantès, que precisou adentrar o submundo e passar por uma série de provações para retornar, 14 anos depois, ao convívio social.

\section{A CATÁBASE DE DANTÈS}

A Eneida de Virgílio tem por objeto a gesta de um herói homérico que sobreviveu à guerra. Para edificar uma nova Troia no Lácio, Eneias levou consigo os penates, deuses tutelares de sua terra natal, enfrentando várias peripécias ao longo do caminho. $\mathrm{O}$ mito da fundação de Roma, então, aparece como recurso político, elaborado poeticamente. Para substancializá-lo, o filho de Anquises precisou sobreviver a intempéries marítimas, combater os rútulos, estabelecer alianças e visitar o mundo dos mortos. O descensus, expediente literário situado no Livro VI, foi formulado com base em grande investimento descritivo e elaborado como condição para a efetiva consumação do heroico, afinal, a catabasis aparece como um "desejo de superação da finitude humana", revelando "as vicissitudes do herói ao confrontá-lo com sua condição mortal e expô-lo ao temor da aniquilação" (Gonçalves \& Mota, 2011, p. 3). Adotado em situações muito diversas, o termo, em geral, relaciona-se ao mundo dos mortos (Bernabé, 2015, p. 31).

Quando visitou seu pai nos Campos Elísios, Eneias pôde contemplar sua descendência. O poema apresenta-nos a justificação mítica da vocação dos Iulli. Para tanto, Virgílio partiu de uma famosa passagem da Ilíada na qual divindades prometeram a Eneias o império sobre o mundo. A lenda existia antes mesmo da composição da Eneida, mas o poeta soube valer-se dela para legitimar as ações de Augusto, contemplado pelo herói troiano por meio da metempsicose. Em termos históricos, o herói figura um rol de virtudes que integram as expectativas de seu presente, ou seja, não é mais a ménis de Aquiles ou a métis de Odisseu a marca decisiva de seu caráter, mas a pietas ${ }^{5}$, atributo integrante do mos maiorum, reconhecido no

5 O termo latino pietate, utilizado para caracterizar Eneias, não pode ser equiparado à piedade em sua conotação cristã. A pietas romana consistia na obediência irrestrita aos deuses e aos superiores hierárquicos. $\mathrm{O}$ adjetivo pius é muito recorrente na Eneida: trata-se de um epíteto que "indica o estrito cumprimento dos deveres para com os deuses, a família e o Estado, cumprindo a vontade de Júpiter, em consonância com o destino" (ver Vasconcellos, 2004). 
próprio princeps que, por meio de Mecenas, patrocinou a poesia de Virgílio.

Eneias e seus companheiros chegaram a Cumas, região situada na costa ocidental da Itália, com o intuito de localizar a sacerdotisa Sibila. O local é reconhecido por um conjunto de galerias, poços, cavernas, acidentes naturais que ajudam a associá-lo às entranhas da terra. Como nos recorda Thiago Mota, o mundo dos mortos mantém características análogas àquelas vivenciadas pelos vivos, reproduzindo suas fronteiras, matizes, hierarquias. Até mesmo as sombras recordam-se e lamentam suas condições. Eneias identifica, ali, sua provação, uma condição que exige a manifestação de seu heroísmo. Só então ele contempla seu destino e nota que precisa agir com virtude para efetuar a vontade dos deuses. Sua missão não se limita ao kléos, isto é, à glória pessoal. O herói, nesse contexto, é aquele que se sente à vontade, nos Campos Elísios, porque percebe virtudes que são suas e sofre ao notar no Tártaro os vícios que jamais reproduziria.

A catábase mais conhecida, no entanto, é a que Dante Alighieri realizou em sua Commedia. Logo no princípio, a personagem encontrou-se numa selva escura, alegoria da vida pecaminosa. No limite da selva há uma colina, mas três feras (uma onça, um leão e uma loba) impedem sua passagem. Prestes a retornar pelo caminho do pecado, notou o avanço de uma sombra: era a alma de Virgílio, que lhe indica um novo caminho, pelo qual Dante seria conduzido pelo Inferno e pelo Purgatório para, em seguida, com o auxílio de Beatriz, conhecer o Paraíso. Para descrever o Inferno, Dante emulou Virgílio. Quanto à cosmografia, imitou Euclides e Ptolomeu
- no centro do universo colocou a Terra imóvel. Jerusalém encontrava-se ao Norte, sobre o abismo do Inferno; no Hemisfério Austral, inabitável, temos a montanha do Purgatório. O Inferno, estado de dor e desesperança eternas, é um abismo profundo formado por nove círculos. Quanto mais profundo o círculo, mais grave o pecado a ser punido. Os castigos, como lembra João Adolfo Hansen (2012), invertem, simetricamente, a abominação dos seus pecados, verdadeira aplicação da pena de talião. O poema, com seu propósito de "remover os que vivem nesta vida do estado de miséria e levá-los para o estado de felicidade", teria sido o resultado edificante dessa experiência, a razão de ser da catábase dantesca.

Edmond Dantès não teria protagonizado uma catábase? Se não estamos mais a tratar do mundo dos mortos (Hades, Averno, Inferno), não seriam as "catacumbas" da Ilha de If um local subterrâneo desprovido de luz, margeado por encostas íngremes, marcado pela condição solitária dos prisioneiros? Não seria um reduto que proporcionava a tão temida morte sem renome? Os rogos de Dantès em meio a esse cenário, as censuras que desferiu contra Deus, não remontam ao cenário de desesperança que caracterizava o submundo?

O protagonista adquiriu, com o abade Faria, a sabedoria (química, matemática, filosofia, línguas, botânica...) e o mapa que conferia acesso às riquezas do cardeal Spada, situadas na Ilha de Monte Cristo. Se desceu ao cárcere da Ilha de If como homem ignorante, pobre e ludibriado, Dantès retornou sábio, enriquecido, movido pela vingança e disposto a enganar aqueles por quem fora enganado. Depois de tornar-se conde, passou a sentir certa aversão e di- 
ficuldade de pronunciar seu antigo nome (como quando resolveu se revelar para $\mathrm{Ca}$ derousse em seu leito de morte). A transformação estava completa.

Ao final do romance, sabemos que os grandes inimigos de Dantès pagaram o preço pela traição: um enlouqueceu, outro cometeu suicídio e Danglars, sua última vítima, foi aprisionado nas profundezas de uma caverna escura e solitária, sendo obrigado a utilizar seus fundos para se alimentar a manter-se vivo. Mais uma catábase, mais uma prisão subterrânea com o intuito de corrigir os excessos do banqueiro, oferecendo-lhe uma lição contra a usura. Por fim, aplacando a sede vingativa, o conde resolveu poupar a vida do prisioneiro, que foi colocado em liberdade empobrecido e, portanto, desenganado.

\section{TRATADO DA VINGANÇA OU DO PERDÃO?}

Nos poemas homéricos ora sobressai a ménis, a ira que imprime em Aquiles força descomunal e excelência guerreira, ora destaca-se a métis, a astúcia prudente que permite a Ulisses enfrentar inúmeras peripécias e manter-se vivo para retornar a Ítaca. Eneias, por sua vez, identificado com a virtude da pietas, fundou uma nova Troia no Lácio, seguindo o destino ditado pelos Fados. Por fim, há a gesta camoniana e o protagonismo de um herói guiado pela reta razão e pela moderação, virtudes escolásticas incentivadas pela Igreja contrarreformada do século XVI, que enaltecia aqueles que atuavam como braço da Providência. A tomar pelo gênero épico, os heróis são nobres, aristocratas, reis.
Já as personagens provenientes de classes menos abastadas, em geral, são figuradas em gêneros como a comédia e a sátira.

$\mathrm{Na}$ Antiguidade greco-latina, as personagens baixas são cômicas, ou melhor, o cômico é o gênero adequado à gente desprovida de nobreza. Na ficção romântica, por outro lado, os homens são fruto da Revolução Francesa, ou seja, a carreira está aberta ao talento na sociedade burguesa. Assim, o que era vulgar e cômico nas sociedades do Antigo Regime poderia tornar-se sério, trágico e épico nas sociedades modernas pós-revolução. Os gêneros cômicos e satíricos, desde os gregos até o Iluminismo, se ocuparam de tipos humanos que, em geral, pertenciam às classes populares. A partir do século XIX, os novos expedientes literários, como o romance, começaram a se ocupar justamente da ascensão dos homens, como é o caso de Julien Sorel, protagonista de $O$ vermelho e o negro (1830), de Stendhal.

A "catábase" de Dantès tornou possível uma ascensão dessa natureza: de marinheiro humilde com soldo precário, tornou-se um conde com ouro o suficiente para patrocinar todos os luxos imagináveis. O protagonista se porta como um agente das forças centrífugas, não havendo limite para o portador de todo esse dinheiro. É, também, agente da Providência, utilizando a justiça divina para legitimar seus interesses particulares. Por fim, frente ao remorso e a despeito do quase perfeito desempenho de seus planos, abandonou o luxo para viver um caso de amor com sua escrava, Haydée, filha de Ali Paxá, o famoso "Leão de Janina". O descensus às catacumbas subterrâneas de If tornou possível sua ascensão financeira, na Ilha de Monte 
Cristo. Ao final, o conhecimento que lhe concedeu o necessário para efetuar sua vingança foi mobilizado para suspendê-la, para dar-lhe um basta.

Por mais que se mostre superior aos demais no decorrer da trama, Dantès sempre buscou estabelecer uma proporção entre crime e castigo, considerando justa esta equivalência: o juiz Villefort deveria ser desacreditado no ofício que, ávido, desejava; Danglars deveria perder aquilo que mais valorizava - o dinheiro; Fernand, por fim, deveria ter sua traição exposta, pois foi por meio dela que conquistou seus títulos nobiliárquicos, ostentados sempre com tanto orgulho.

Dumas retratou não um guerreiro semideus irado ou um tirano dominado pelo furor vingativo, como fizeram Homero e Sêneca, mas um homem comum que ascendeu por meios insólitos, disposto a tirar de seus desafetos o objeto que tanto ambicionaram. O protagonista de Dumas utilizou seus talentos (adquiridos a duras penas, por meio de seu maestro, o abade Faria) e uma imensa riqueza para obscurecer suas origens plebeias. Admite-se, aí, numa mesma personagem, o ato vingador e o heroísmo: trata-se de um monstro, segundo os preceitos antigos, por reunir em si atributos virtuosos e viciosos - um herói byroniano, conforme a análise de Candido, pois Dantès portava-se de maneira contra- ditória e ambígua. A contradição torna-se verossímil no século XIX, momento em que a honestidade associa-se aos assuntos pessoais descompromissados com a aparência pública exigida nos ambientes cortesãos.

O Romantismo desferiu um golpe certeiro contra a retórica ao alegar repúdio ao artifício, ainda que tenha adotado outras convenções para sustentar uma suposta verdade profunda, interna, subjetiva, dotando o sujeito de complexidade psicológica. Divergindo-se de Atreu, que, na tragédia senequiana, operou sua vingança por meio de mentiras, Dantès agiu conforme sua versão da verdade, que guardou no seu íntimo para direcionar as ações de sua personagem. O artifício permaneceu, porém com novas roupagens, pois a vingança de Dantès alcançava seu auge quando ele achava ocasião para revelar sua verdadeira identidade.

Frente à catábase/transformação de Dantès e à postura que assumiu perante Danglars, perdoando suas faltas depois de contemplá-lo empobrecido, como ler o romance de Dumas: um tratado da vingança, à maneira de Antonio Candido, ou um tratado sobre o perdão? Como é típico do homem deleitar-se mais com o sofrimento, não é de se estranhar que a ideia de vingança tenha prevalecido, afinal, a dor infligida é mais palpável que o sofrimento poupado. 


\section{REFERÊNCIAS}

BERNABÉ, A. "What is a katábasis? The descent into the Netherworld in Greece and the ancient Near East". Les Études Classiques, 83, 2015.

BURKE, E. Uma investigação filosófica sobre a origem de nossas ideias do sublime e do belo. Campinas, Editora da Universidade de Campinas, 1993.

CAMPOS, A. M. "A (im)piedade de Aquiles". Letras Clássicas, n. 5, 2001.

CANDIDO, A. Tese e antítese. Rio de Janeiro, Ouro Sobre Azul, 2017.

DIBBERN, C. H. "A imagem do recuo do Sol na tragédia Tiestes de Sêneca". Codex, v. 2, n. 2, 2010, pp. 4-13.

DUMAS, A. O Conde de Monte Cristo. Tradução de A. Telles e R. Lacerda. Rio de Janeiro, Zahar, 2012.

FONSECA, C. A. L. "Horácio em A vida de Soares de Passos". Humanitas. Coimbra, Instituto de Letras da Universidade de Coimbra, 1967.

GONÇALVES, A. T. M.; MOTA, T. E. A. “Do Tártaro aos Vergéis Elísios: a jornada do descensus, os exempla e os espaços do Averno na Eneida de Virgílio". Mneme, 12 (30), 2011.

GRIMAL, P. O século de Augusto. São Paulo, Edições 70, 2008.

HANSEN, J. A. "A máquina do mundo", in A. Novaes (org.). Poetas que pensaram o mundo. São Paulo, Companhia das Letras, 2005.

HANSEN, J. A. "Notas de leitura”, in D. Alighieri. Divina Comédia. Tradução e notas de J. T. Ziller. Campinas, Ateliê Editorial, 2012.

JONES, D. "Ultima Thule: Arthur Gordon Pym, the Polar Imaginary and the Hollow Earth". The Edgar Allan Poe Review, v. 11, n. 1, 2010, pp. 51-69.

LESTRINGANT, F. "O impacto das descobertas geográficas na concepção política e social da utopia", in Morus - Utopia e Renascimento, n. 3, 2006.

MARQUES, L. "Vasari e a superação da Antiguidade: do nec plus ultra ao plus ultra", in A. Ragazzi et al. (orgs.). Interdisciplinaridade sobre o Renascimento italiano. São Paulo, Editora Unifesp, 2017.

MEYER, M. Folhetim: uma história. São Paulo, Companhia das Letras, 1996.

NADAF, Y. J. "O romance-folhetim francês no Brasil: um percurso histórico". Letras, v. 19, n. 2, Santa Maria, 2009, pp. 119-138.

PARRA I ALBÀ, M. "La isla en la novela popular francesa: El Conde de Monte Cristo de Alexandre Dumas", in L'ull Crític, n. 4-5, 1999.

RIBEIRO, J. A. Imprensa e ficção no século XIX. Edgar Allan Poe e a narrativa de Arthur Gordon Pym. São Paulo, Editora da Universidade Estadual Paulista, 1996.

RODRIGUES, G. F. O ciclope de Eurípedes: estudo e tradução. Dissertação de mestrado. São Paulo, Faculdade de Filosofia, Letras e Ciências Humanas da USP, 2016.

SÊNECA. Da tranquilidade da alma. Tradução e notas de G. D. Leoni. Col. Os Pensadores, 3a ed. São Paulo, Abril Cultural, 1985.

SÊNECA. Tiestes. Tradução, notas e estudos de J. E. S. Lohner. Curitiba, Ed. UFPR, 2018. TORRES, E. C. "Folhetim, uma história sem fim: dos primeiros jornais de massa à internet".

Revista do Programa de Pós-Graduação em Comunicação, v. 6, n. 2, 2012, pp. 1-26.

VASCONCELLOS, P. S. de. "Apresentação", in Virgílio. Eneida de Virgílio. Tradução de J. V. B.

Feio e J. M. Costa e Silva. São Paulo, Martins Fontes, 2004.

VERNANT, J-P. “A bela morte e o cadáver ultrajado”. Discurso, n. 9, 1978, pp. 31-62. 